\title{
Marinomonas arenicola sp. nov., isolated from marine sediment
}

\author{
Lyudmila A. Romanenko, ${ }^{1}$ Naoto Tanaka ${ }^{2}$ and Galina M. Frolova ${ }^{1}$ \\ ${ }^{1}$ Pacific Institute of Bioorganic Chemistry, Far-Eastern Branch, Russian Academy of Sciences, \\ Prospect 100 Let Vladivostoku 159, 690022 Vladivostok, Russia \\ ${ }^{2}$ NODAI Culture Collection Center, Tokyo University of Agriculture, 1-1-1 Sakuragaoka, Setagaya-ku, \\ Tokyo 156-8502, Japan
}

Correspondence

Lyudmila A. Romanenko

Iro@piboc.dvo.ru

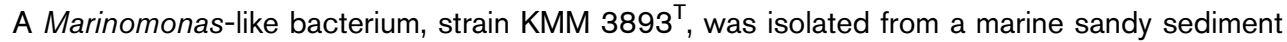
collected close to shore from the Sea of Japan and subjected to a phenotypic and phylogenetic study. Comparative 16S rRNA gene sequence analysis confirmed the novel strain's assignment to

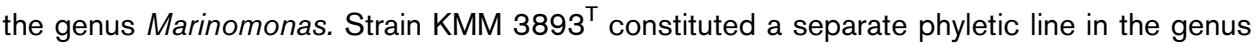
Marinomonas, sharing $<97 \%$ sequence similarity with respect to other recognized Marinomonas species. Chemotaxonomically, strain $\mathrm{KMM} 3893^{\top}$ contained the predominant fatty acids $\mathrm{C}_{18: 1} \omega 7 c, \mathrm{C}_{16: 1} \omega 7 c$ and $\mathrm{C}_{16: 0}$ and had a DNA G+C content of $50.0 \mathrm{~mol} \%$. On the basis of the phylogenetic analysis and physiological and biochemical characterization, strain KMM $3893^{\top}$ represents a novel species of the genus Marinomonas, for which the name Marinomonas

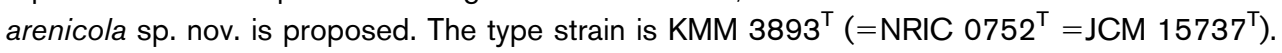

The genus Marinomonas was created by Van Landschoot \& De Ley (1983) as the result of the reclassification of two species, Alteromonas communis and Alteromonas vaga, as Marinomonas communis and Marinomonas vaga (Baumann et al., 1972). Subsequently, the genus has been expanded with the addition of Marinomonas mediterranea (Solano \& Sanchez-Amat, 1999), M. primoryensis (Romanenko et al., 2003), M. aquimarina (Macián et al., 2005), M. pontica (Ivanova et al., 2005), M. ushuaiensis (Prabagaran et al., 2005), M. dokdonensis (Yoon et al., 2005), M. polaris (Gupta et al., 2006), M. ostreistagni (Lau et al., 2006) and M. arctica (Zhang et al., 2008).

Strain KMM $3893^{\mathrm{T}}$ was isolated from a marine sandy sediment sample from the Sea of Japan, collected close to shore at a water depth of $1 \mathrm{~m}$, as described previously (Romanenko et al., 2004). The bacterium KMM $3893^{\mathrm{T}}$ grew aerobically at $25-28{ }^{\circ} \mathrm{C}$ on marine 2216 agar (MA) or in marine broth $(\mathrm{MB})$, on TSA and on seawater agar (containing $5 \mathrm{~g}$ peptone, $2.5 \mathrm{~g}$ yeast extract, $1.0 \mathrm{~g}$ glucose, $0.2 \mathrm{~g} \mathrm{~K}_{2} \mathrm{HPO}_{4}, 0.05 \mathrm{~g} \mathrm{MgSO}_{4}, 750 \mathrm{ml}$ seawater, $250 \mathrm{ml}$ distilled water, $15.0 \mathrm{~g}$ agar). The strain was stored at $-80{ }^{\circ} \mathrm{C}$ in MB supplemented with $30 \%$ (v/v) glycerol. Motility was observed by the hanging-drop method as described by Gerhardt et al. (1994). Phenotypic properties were tested according to the standard methods described by Smibert \&

The GenBank/EMBL/DDBJ accession number for the $16 \mathrm{~S}$ rRNA gene sequence of strain $\mathrm{KMM} 3893^{\top}$ is $\mathrm{AB} 467281$.

A maximum-parsimony phylogenetic tree based on 165 rRNA gene sequences is available as supplementary material with the online version of this paper.
Krieg (1994). The oxidation/fermentation medium of Leifson (1963) for marine bacteria was used to test for acid production from carbohydrates with $1 \%(\mathrm{w} / \mathrm{v})$ of each compound. Growth at different temperatures and $\mathrm{pH}$ and in the presence of various $\mathrm{NaCl}$ concentrations and antibiotics was studied as described previously (Romanenko et al., 2003, 2004, 2005). In addition, biochemical tests were carried out using API 20NE, API ID 32GN and API 50CH test kits (bioMérieux), according to the manufacturer's instructions. For comparative fatty acid analysis, strain KMM $3893^{\mathrm{T}}$, M. communis CIP $74.1^{\mathrm{T}}$ and M. primoryensis KMM $3633^{\mathrm{T}}$ were cultivated on MA at $28{ }^{\circ} \mathrm{C}$ and in $\mathrm{MB}$ at $22{ }^{\circ} \mathrm{C}$ for 3 days and lipids were extracted using the chloroform/methanol extraction method of Bligh \& Dyer (1959). Fatty acid methyl esters were obtained by alkaline methanolysis $(15 \% \mathrm{NaOH} /$ methanol) and hexane extraction and were analysed using a GLC-MS Hewlett Packard model 6890 gas chromatograph equipped with a HP 5 MS $5 \%$ phenyl methyl siloxane capillary column $(30 \mathrm{~m} \times 250 \mu \mathrm{m} \times 0.25 \mu \mathrm{m})$ and connected to a Hewlett Packard model 5973 mass spectrometer. The DNA base composition was determined as described by Marmur \& Doty (1962) and Owen et al. (1969). A 16S rRNA gene sequence of 1523 nucleotides was determined for strain KMM $3893^{\mathrm{T}}$ as described by Shida et al. (1997). The sequence obtained was compared with 16S rRNA gene sequences retrieved from the EMBL/ GenBank/DDBJ databases with the FASTA program (Pearson \& Lipman, 1988). Phylogenetic analysis of $16 \mathrm{~S}$ rRNA gene sequences was performed using the software package MEGA 4 (Tamura et al., 2007) after alignment using 


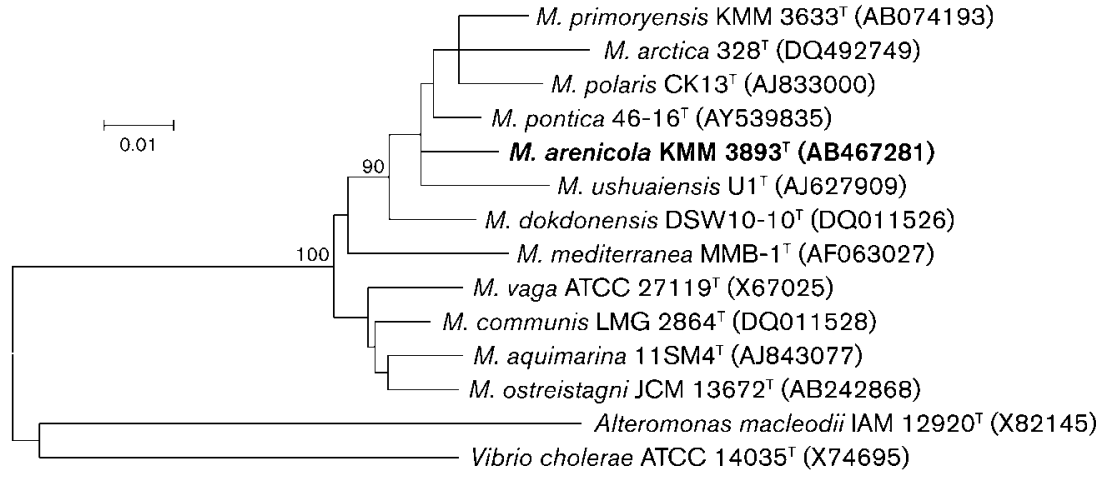

Fig. 1. Neighbour-joining tree based on $16 \mathrm{~S}$ rRNA gene sequences showing the phylogenetic relationships between strain $\mathrm{KMM} 3893^{\top}$ and Marinomonas species. Bootstrap values $(>90 \%)$ based on 1000 replications are shown at branch nodes. The sequences of Vibrio cholerae ATCC $14035^{\top}$ and Alteromonas macleodii IAM $12920^{\top}$ were used as the outgroup. Bar, 0.01 substitutions per nucleotide position.
CLUSTAL X version 1.83 (Thompson et al., 1997). Trees were constructed using the neighbour-joining and maximumparsimony methods and distances were calculated according to Kimura's two-parameter model. Bootstrap analysis of 1000 replicates was used to estimate the robustness of the phylogenetic trees.

Comparative 16S rRNA gene sequence analysis showed that strain KMM $3893^{\mathrm{T}}$ belonged to the genus Marinomonas and formed a distinct lineage (Fig. 1). The same relationship was also evident in the $16 \mathrm{~S}$ rRNA gene sequence dendrogram that was generated using the maximum-parsimony algorithm (Supplementary Fig. S1, available in IJSEM Online). Strain KMM $3893^{\mathrm{T}}$ shared the highest 16S rRNA gene sequence similarities with $M$. pontica $46-16^{\mathrm{T}}(96.9 \%)$ and $M$. dokdonensis DSW $10-10^{\mathrm{T}}$ (96.7\%), lower values with $M$. ushuaiensis $\mathrm{U1}^{\mathrm{T}}(96.1 \%)$, M. vaga ATCC $27119^{\mathrm{T}}$ and $M$. communis LMG $2864^{\mathrm{T}}$ (95.6\% each) and less than $95 \%$ similarity with the other members of the genus Marinomonas. 16S rRNA gene sequence similarity of $97.0 \%$ was proposed by Stackebrandt \& Goebel (1994) and subsequently reevaluated to $98.7 \%$ by Stackebrandt \& Ebers (2006) as a criterion for species discrimination. Taking this into consideration, we concluded that the $16 \mathrm{~S}$ rRNA gene sequence similarities between strain KMM $3893^{\mathrm{T}}$ and type strains of Marinomonas species are low enough to exclude the assignment of the strain to any of the recognized Marinomonas species.

For comparison purposes, the fatty acid profiles of three strains, KMM $3893^{\mathrm{T}}$, M. communis CIP $74.1^{\mathrm{T}}$ and $M$. primoryensis $\mathrm{KMM} 3633^{\mathrm{T}}$, grown on $\mathrm{MA}$ and in $\mathrm{MB}$ at different temperatures, were examined. The profiles are detailed in Table 1. For each strain, no noticeable differences were found that were dependent on culture conditions. M. communis CIP $74.1^{\mathrm{T}}$, M. primoryensis $\mathrm{KMM}$ $3633^{\mathrm{T}}$ and strain $\mathrm{KMM} 3893^{\mathrm{T}}$ contained $\mathrm{C}_{18: 1} \omega 7 c$, $\mathrm{C}_{16: 1} \omega 7 c$ and $\mathrm{C}_{16: 0}$ as the major fatty acids. These results are in accordance with the data reported for $M$. communis, M. vaga, M. mediterranea (Mikhailov et al., 2006), M. primoryensis (Romanenko et al., 2003), M. dokdonensis (Yoon et al., 2005), M. pontica (Ivanova et al., 2005), M. ostreistagni (Lau et al., 2006) and M. arctica (Zhang et al.,
2008). However, the data obtained disagreed with the results found by Prabagaran et al. (2005) and Gupta et al. (2006), who reported the presence of significant percentages of iso- $\mathrm{C}_{16: 0}(13.5,11.3,16.1$ and $18.5 \%)$ and minor amounts of $\mathrm{C}_{16: 0}(1.1,1.1,2.1$ and $6.2 \%)$ in the fatty acid profiles of $M$. communis, $M$. primoryensis, $M$. ushuaiensis and $M$. polaris, respectively. In the present study, the fatty acid profiles of strain KMM $3893^{\mathrm{T}}$, M. communis and $M$. primoryensis appeared to be similar to each other in terms of the presence of $\mathrm{C}_{18: 1} \omega 7 c, \mathrm{C}_{16: 1} \omega 7 c$ and $\mathrm{C}_{16: 0}$ as the predominant fatty acids and the absence of iso- $\mathrm{C}_{16: 0}$, independent of the growth conditions. In addition, $M$. communis CIP $74.1^{\mathrm{T}}$ revealed a slight difference in the absence of $\mathrm{C}_{12: 1}$ and strain $\mathrm{KMM} 3893^{\mathrm{T}}$ differed by possessing a small amount of $\mathrm{C}_{17: 1}$.

The DNA $\mathrm{G}+\mathrm{C}$ content of strain $\mathrm{KMM} 3893^{\mathrm{T}}$ was determined to be $50.0 \mathrm{~mol} \%$, which is in line with those

Table 1. Cellular fatty acid compositions of strain KMM $3893^{\top}$, M. communis CIP $74.1^{\top}$ and M. primoryensis KMM $3633^{\top}$

Strains: 1, Marinomonas arenicola sp. nov. KMM $3893^{\mathrm{T}}$; 2, M. communis CIP $74.1^{\mathrm{T}}$; 3, M. primoryensis $\mathrm{KMM} 3633^{\mathrm{T}}$. Data were obtained in this study. Strains were grown on MA at $28{ }^{\circ} \mathrm{C}$ (a) and in $\mathrm{MB}$ at $22{ }^{\circ} \mathrm{C}$ (b). Values are percentages of total fatty acids; major components are highlighted in bold. -, Not detected.

\begin{tabular}{|c|c|c|c|c|c|c|}
\hline \multirow[t]{2}{*}{ Fatty acid } & \multicolumn{2}{|c|}{1} & \multicolumn{2}{|c|}{2} & \multicolumn{2}{|c|}{3} \\
\hline & $\mathbf{a}$ & b & $\mathbf{a}$ & b & $\mathbf{a}$ & b \\
\hline $\mathrm{C}_{10: 0} 3-\mathrm{OH}$ & 9.7 & 8.9 & 10.4 & 3.7 & 4.8 & 5.0 \\
\hline $\mathrm{C}_{12: 1}$ & 2.1 & 3.0 & - & - & 4.4 & 6.0 \\
\hline$C_{12: 0}$ & 11.0 & 10.7 & 5.6 & 4.4 & 0.8 & - \\
\hline$C_{13: 0}$ & 1.3 & - & - & - & - & - \\
\hline$C_{14: 0}$ & 1.3 & - & 2.2 & 1.9 & - & - \\
\hline $\mathrm{C}_{16: 1} \omega 7 c$ & 10.2 & 13.0 & 15.9 & 22.2 & 22.1 & 23.5 \\
\hline$C_{16: 0}$ & 17.4 & 16.0 & 11.4 & 10.8 & 11.9 & 14.4 \\
\hline$C_{17: 1}$ & 3.2 & 2.8 & - & 0.2 & - & - \\
\hline $\mathrm{C}_{18: 1} \omega 7 c$ & 31.0 & 38.8 & 44.2 & 53.2 & 37.0 & 38.2 \\
\hline $\mathrm{C}_{18: 1} \omega 9 c$ & - & - & 0.1 & 0.4 & - & - \\
\hline$C_{18: 0}$ & 4.2 & 4.1 & 2.5 & 2.6 & 5.6 & 5.8 \\
\hline
\end{tabular}


Table 2. Phenotypic characteristics of $M$. arenicola sp. nov. KMM $3893^{\top}$ and related Marinomonas species

Taxa: 1, M. arenicola sp. nov. KMM 3893 (data from this study); 2, M. ushuaiensis (Prabagaran et al., 2005); 3, M. pontica (Ivanova et al., 2005); 4, M. dokdonensis (Yoon et al., 2005); 5, M. primoryensis (Romanenko et al., 2003); 6, M. communis (Baumann et al., 1972); 7, M. vaga (Baumann et al., 1972); 8, M. mediterranea (Solano \& Sanchez-Amat, 1999). All strains are positive for motility and requirement for sodium ions for growth. All strains are negative for arginine dihydrolase and production of indole and $\mathrm{H}_{2} \mathrm{~S}$. +, Positive; w, weak; v, variable between strains; -, negative; ND, no data available.

\begin{tabular}{|c|c|c|c|c|c|c|c|c|}
\hline Characteristic & 1 & 2 & 3 & 4 & 5 & 6 & 7 & 8 \\
\hline Pigmentation & None & None & None & None & Yellowish & None & None & Melanin-like \\
\hline Oxidase & - & - & + & + & + & + & - & - \\
\hline Nitrate reduction & - & - & - & - & - & - & - & + \\
\hline \multicolumn{9}{|l|}{ Tolerance of $\mathrm{NaCl}$ at: } \\
\hline $8 \%(w / v)$ & + & - & + & + & $\mathrm{W}^{*}$ & + & + & ND \\
\hline $10 \%(\mathrm{w} / \mathrm{v})$ & + & - & + & + & - & $+^{*}$ & $+^{*}$ & $\mathrm{ND}$ \\
\hline \multicolumn{9}{|l|}{ Growth at: } \\
\hline $4{ }^{\circ} \mathrm{C}$ & + & + & + & + & + & - & - & - \\
\hline $35{ }^{\circ} \mathrm{C}$ & + & - & - & + & - & + & + & - \\
\hline $37^{\circ} \mathrm{C}$ & + & - & - & + & - & + & - & - \\
\hline $40{ }^{\circ} \mathrm{C}$ & - & - & - & - & - & + & - & - \\
\hline \multicolumn{9}{|l|}{ Hydrolysis of: } \\
\hline Gelatin & - & - & - & - & - & - & - & + \\
\hline Tween 80 & - & - & - & + & - & - & - & + \\
\hline Starch & - & + & - & - & - & - & - & - \\
\hline \multicolumn{9}{|l|}{ Utilization of: } \\
\hline D-Glucose & - & + & + & ND & $+\dagger$ & + & + & + \\
\hline Maltose & - & $\mathrm{W}$ & + & + & + & $\mathrm{V}$ & $\mathrm{V}$ & - \\
\hline $\mathrm{N}$-Acetyl-D-glucosamine & - & ND & ND & ND & + & - & + & $\mathrm{ND}$ \\
\hline$m$-Hydroxybenzoate & - & + & + & - & + & + & + & - \\
\hline Mannitol & - & - & ND & $\mathrm{ND}$ & + & + & + & $\mathrm{ND}$ \\
\hline Malate & - & - & + & + & $+\dagger$ & + & + & + \\
\hline L-Arginine & - & - & + & ND & $\mathrm{V}$ & + & $\mathrm{V}$ & $\mathrm{ND}$ \\
\hline L-Lysine & - & - & + & ND & + & + & $\mathrm{V}$ & ND \\
\hline DNA G $+C$ content $(\mathrm{mol} \%)$ & 50.0 & 43.6 & 46.5 & $45.3-45.7$ & $45.3-45.6$ & $46.0-48.0$ & $47.0-49.0$ & $46.3 \pm 0.9$ \\
\hline
\end{tabular}

${ }^{\star}$ Data for M. primoryensis KMM $3633^{\mathrm{T}}$, M. communis CIP $74.1^{\mathrm{T}}$ and M. vaga CIP $103202^{\mathrm{T}}$ obtained in this study. $\dagger$. primoryensis $\mathrm{KMM} 3633^{\mathrm{T}}$ tested weakly positive in this study.

reported for Marinomonas (43.6-49.0 mol\%) although considerably higher than that for M. usuaiensis $\mathrm{U}^{\mathrm{T}}$ (43.6 mol\%) (Table 2). Differential phenotypic features of strain $\mathrm{KMM} 3893^{\mathrm{T}}$ and related species of the genus Marinomonas are listed in Table 2 and in the species description. It is notable that strain KMM $3893^{\mathrm{T}}$ was susceptible to 16 of the 20 antibiotics that were tested ( $\mu \mathrm{g}$ per disc unless otherwise stated): ampicillin (10), benzylpenicillin (10 U), vancomycin (30), gentamicin (10), kanamycin (30), carbenicillin (100), chloramphenicol (30), neomycin (30), ofloxacin (5), polymyxin (300 U), rifampicin (5), streptomycin (30), erythromycin (15), tetracycline (30), cephazolin (30) and cephalexin (30). Strain KMM $3893^{\mathrm{T}}$ was resistant to nalidixic acid (30), lincomycin (15), oxacillin (10) and oleandomycin (15). The isolate could be distinguished from recognized Marinomonas species in not being able to assimilate most compounds in the API ID $32 \mathrm{GN}$, API $20 \mathrm{NE}$ and API $50 \mathrm{CH}$ systems. Strain KMM $3893^{\mathrm{T}}$ was similar to M. ushuaiensis (Prabagaran et al., 2005) in terms of their lack of oxidase and nitrate reduction activities and carbon assimilation pattern, but differed in not being able to degrade starch or to utilize D-glucose or $m$-hydroxybenzoate and by being able to grow at higher temperatures and to tolerate $8-10 \% \mathrm{NaCl}$.

Strain KMM $3893^{\mathrm{T}}$ could be distinguished from other recognized Marinomonas species on the basis of combined differential phenotypic characteristics and phylogenetic distinctiveness. Therefore, it is proposed that strain KMM $3893^{\mathrm{T}}$ is assigned to the genus Marinomonas as representing a novel species, Marinomonas arenicola sp. nov.

\section{Description of Marinomonas arenicola sp. nov.}

Marinomonas arenicola (a.re.ni'co.la. L. n. arena sand; L. suff. - cola inhabitant, dweller; N.L. n. arenicola a sanddweller).

Cells are aerobic, Gram-negative, oxidase-negative, catalase-positive, motile rods (approx. $2 \mu \mathrm{m}$ long). Colonies are non-pigmented, semi-transparent, shiny and smooth 
with regular edges, 2-3 $\mathrm{mm}$ in diameter on MA. Growth occurs at $4-37{ }^{\circ} \mathrm{C}$ (optimum 25-28 ${ }^{\circ} \mathrm{C}$ ) but not at temperatures above $38{ }^{\circ} \mathrm{C}$. Sodium ions are essential for growth. Growth is observed with $0.5-10 \%(w / v) ~ \mathrm{NaCl}$ but not with $12 \% \mathrm{NaCl}$. Grows at $\mathrm{pH} 5.5-9.5$ (optimum $\mathrm{pH}$ 6.5-8.0). Negative for hydrolysis of casein, gelatin, Tween 80, starch, chitin and DNA and production of $\mathrm{H}_{2} \mathrm{~S}$. On medium containing L-tyrosine, does not produce melanin-like pigments or clearance zones. Acid is formed from D-xylose, but not from D-glucose, D-mannitol, sucrose, lactose, maltose, D-galactose, D-mannose, cellobiose, D-sorbitol, L-arabinose or L-rhamnose. According to API 20NE tests, positive for $\beta$-galactosidase activity ( $p$ nitrophenyl D-galactopyranoside hydrolysis) and negative for reduction of nitrate, production of indole, urease and arginine dihydrolase, acidification of glucose, hydrolysis of gelatin and aesculin and assimilation of D-glucose, Dmannitol, maltose, L-arabinose, D-mannose, $N$-acetylglucosamine, D-gluconate, caprate, adipate, L-malate, citrate and phenylacetate. According to API 50CH tests, utilizes potassium 5-ketogluconate and potassium 2-ketogluconate weakly, but does not utilize glycerol, erythritol, D- or Larabinose, $\mathrm{D}$-ribose, $\mathrm{D}$ - or L-xylose, $\mathrm{D}$-adonitol, methyl $\beta$-Dxylopyranoside, D-galactose, $\mathrm{D}$-glucose, $\mathrm{D}$-fructose, $\mathrm{D}$-mannose, L-sorbose, L-rhamnose, dulcitol, inositol, D-mannitol, D-sorbitol, methyl $\alpha$-D-mannopyranoside, methyl $\alpha$-Dglucopyranoside, $N$-acetylglucosamine, amygdalin, arbutin, aesculin, salicin, cellobiose, maltose, lactose, melibiose, sucrose, trehalose, inulin, melezitose, raffinose, starch, glycogen, xylitol, gentiobiose, turanose, D-lyxose, D-tagatose, D- or L-fucose, L- or D-arabitol or gluconate. According to the API ID 32GN tests, does not assimilate itaconic acid, suberic acid, sodium malonate, sodium acetate, lactic acid, propionic acid, capric acid, trisodium citrate, L-alanine, L-proline, 3-hydroxybutyric acid, 3- or 4hydroxybenzoic acid, potassium 5-ketogluconate, potassium 2-ketogluconate, glycogen, D-mannitol, L-fucose, D-sorbitol, L-rhamnose, inositol, L-arabinose, L-serine, valeric acid or L-histidine. Contains $\mathrm{C}_{18: 1} \omega 7 c, \mathrm{C}_{16: 0}$ and $\mathrm{C}_{16: 1} \omega 7 c$ as the predominant fatty acids. Susceptible to ampicillin, benzylpenicillin, vancomycin, gentamicin, kanamycin, carbenicillin, chloramphenicol, neomycin, ofloxacin, polymyxin, rifampicin, streptomycin, erythromycin, tetracycline, cephazolin and cephalexin. Resistant to nalidixic acid, lincomycin, oxacillin and oleandomycin. The DNA $\mathrm{G}+\mathrm{C}$ content of the type strain is $50 \mathrm{~mol} \%$ (thermal denaturation).

The type strain, KMM $3893^{\mathrm{T}}$ (=NRIC $0752^{\mathrm{T}}=\mathrm{JCM}$ $15737^{\mathrm{T}}$ ), was isolated from a marine sandy sample from the Sea of Japan, Russia.

\section{Acknowledgements}

We would like to thank Dr Chantal Bizet (Collection de l'Institut Pasteur) for providing M. communis CIP $74.1^{\mathrm{T}}$ and $M$. vaga CIP $103202^{\mathrm{T}}$. This study was supported by a grant from the Presidium of the Far-Eastern Branch of Russian Academy of Sciences for 'Search of
Marine Heterotrophic Bacteria Biodiversity' and by a grant from the Presidium of RAS for 'Molecular and Cell Biology'.

\section{References}

Baumann, L., Baumann, P., Mandel, M. \& Allen, R. D. (1972). Taxonomy of aerobic marine eubacteria. J Bacteriol 110, 402-429.

Bligh, E. G. \& Dyer, W. J. (1959). A rapid method of total lipid extraction and purification. Can J Biochem Physiol 37, 911-917.

Gerhardt, P., Murray, R. G. E., Wood, W. A. \& Krieg, N. R. (editors) (1994). Methods for General and Molecular Bacteriology. Washington, DC: American Society for Microbiology.

Gupta, P., Chaturvedi, P., Pradhan, S., Delille, D. \& Shivaji, S. (2006). Marinomonas polaris sp. nov., a psychrohalotolerant strain isolated from coastal sea water off the subantarctic Kerguelen islands. Int J Syst Evol Microbiol 56, 361-364.

Ivanova, E. P., Onyshchenko, O. M., Christen, R., Lysenko, A. M., Zhukova, N. V., Shevchenko, L. S. \& Kiprianova, E. A. (2005). Marinomonas pontica sp. nov., isolated from the Black Sea. Int J Syst Evol Microbiol 55, 275-279.

Lau, K. W. K., Ren, J., Wai, N. L. M., Lau, S. C. L., Qian, P.-Y., Wong, P.-K. $\& \mathrm{Wu}, \mathrm{M}$. (2006). Marinomonas ostreistagni sp. nov., isolated from a pearl-oyster culture pond in Sanya, Hainan Province, China. Int J Syst Evol Microbiol 56, 2271-2275.

Leifson, E. (1963). Determination of carbohydrate metabolism of marine bacteria. J Bacteriol 85, 1183-1184.

Macián, M. C., Arahal, D. R., Garay, E. \& Pujalte, M. J. (2005). Marinomonas aquamarina sp. nov., isolated from oysters and seawater. Syst Appl Microbiol 28, 145-150.

Marmur, J. \& Doty, P. (1962). Determination of the base composition of deoxyribonucleic acid from its thermal denaturation temperature. J Mol Biol 5, 109-118.

Mikhailov, V. V., Romanenko, L. A. \& Ivanova, E. P. (2006). The genus Alteromonas and related proteobacteria. In The Prokaryotes: a Handbook on the Biology of Bacteria, 3rd edn, vol. 6, pp. 597-645. Edited by M. Dworkin, S. Falkow, E. Rosenberg, K. H. Schleifer \& E. Stackebrandt. New York: Springer.

Owen, R. J., Hill, L. R. \& Lapage, S. P. (1969). Determination of DNA base composition from melting profiles in dilute buffers. Biopolymers 7, 503-516.

Pearson, W. R. \& Lipman, D. J. (1988). Improved tools for biological sequence comparison. Proc Natl Acad Sci U S A 85, 2444-2448.

Prabagaran, S. R., Suresh, K., Manorama, R., Delille, D. \& Shivaji, S. (2005). Marinomonas ushuaiensis sp. nov., isolated from coastal sea water in Ushuaia, Argentina, sub-Antarctica. Int J Syst Evol Microbiol 55, 309-313.

Romanenko, L. A., Uchino, M., Mikhailov, V. V., Zhukova, N. V. \& Uchimura, T. (2003). Marinomonas primoryensis sp. nov., a novel psychrophile isolated from coastal sea-ice in the Sea of Japan. Int $J$ Syst Evol Microbiol 53, 829-832.

Romanenko, L. A., Schumann, P., Rohde, M., Mikhailov, V. V. \& Stackebrandt, E. (2004). Reinekea marinisedimentorum gen. nov., sp. nov., a novel gammaproteobacterium from marine coastal sediments. Int J Syst Evol Microbiol 54, 669-673.

Romanenko, L. A., Uchino, M., Falsen, E., Frolova, G. M., Zhukova, N. V. \& Mikhailov, V. V. (2005). Pseudomonas pachastrellae sp. nov. isolated from a marine sponge. Int J Syst Evol Microbiol 55, 919924.

Shida, O., Takagi, H., Kadowaki, K., Nakamura, L. K. \& Komagata, K. (1997). Transfer of Bacillus alginolyticus, Bacillus chondroitinus, Bacillus curdlanolyticus, Bacillus glucanolyticus, Bacillus kobensis, and 
Bacillus thiaminolyticus to the genus Paenibacillus and emended description of the genus Paenibacillus. Int J Syst Bacteriol 47, 289298.

Smibert, R. M. \& Krieg, N. R. (1994). Phenotypic characterization. In Methods for General and Molecular Bacteriology, pp. 607-655. Edited by P. Gerhardt, R. G. E. Murray, W. A. Wood \& N. R. Krieg. Washington, DC: American Society for Microbiology.

Solano, F. \& Sanchez-Amat, A. (1999). Studies on the phylogenetic relationships of melanogenic marine bacteria: proposal of Marinomonas mediterranea sp. nov. Int J Syst Bacteriol 49, 1241-1246.

Stackebrandt, E. \& Ebers, J. (2006). Taxonomic parameters revisited: tarnished gold standards. Microbiol Today 33, 152-155.

Stackebrandt, E. \& Goebel, B. M. (1994). Taxonomic note: a place for DNA-DNA reassociation and $16 \mathrm{~S}$ rRNA sequence analysis in the present species definition in bacteriology. Int J Syst Bacteriol 44, 846849.
Tamura, K., Dudley, J., Nei, M. \& Kumar, S. (2007). MEGA 4: molecular evolutionary genetics analysis (MEGA) software version 4.0. Mol Biol Evol 24, 1596-1599.

Thompson, J. D., Gibson, T. J., Plewniak, F., Jeanmougin, F. \& Higgins, D. G. (1997). The CLUSTAL_X windows interface: flexible strategies for multiple sequence alignment aided by quality analysis tools. Nucleic Acids Res 25, 4876-4882.

Van Landschoot, A. \& De Ley, J. (1983). Intra- and intergeneric similarities of the rRNA cistrons of Alteromonas, Marinomonas (gen. nov.) and some other gram-negative bacteria. J Gen Microbiol 129, 3057-3074.

Yoon, J.-H., Kand, S.-J. \& Oh, T.-K. (2005). Marinomonas dokdonensis sp. nov., isolated from sea water. Int J Syst Evol Microbiol 55, 2303-2307.

Zhang, D. C., Li, H. R., Xin, Y. H., Liu, H. C., Chen, B., Chi, Z. M., Zhou, P. J. \& $\mathrm{Yu}, \mathrm{Y}$. (2008). Marinomonas arctica sp. nov., a psychrotolerant bacterium isolated from the Arctic. Int J Syst Evol Microbiol 58, 1715-1718. 